\title{
Clinical and epidemiological profile of the child population diagnosed with central nervous system cancer in Medellin, Colombia
}

\author{
Juan P. Orozco-Forero ${ }^{1}$, Lina M. Martínez-Sánchez ${ }^{2 *}$, Ana P. Pamplona-Sierra², \\ Ma. de los Ángeles Rodríguez-Gázquez ${ }^{3}$, Ana C. Toro-Moreno ${ }^{4}$, Luis F. Álvarez-Hernández ${ }^{4}$, \\ Laura I. Jaramillo-Jaramillo4 ${ }^{4}$ Daniel Gallego-González ${ }^{4}$, Laura Serna-Vélez ${ }^{4}$ and José A. Betancur-Vergara ${ }^{5}$ \\ ${ }^{1}$ Department of Pediatrics, Clínica Universitaria Bolivariana; ${ }^{2}$ Faculty of Medicine, Universidad Pontificia Bolivariana; ${ }^{3}$ Nursing Faculty, Universidad \\ de Antioquia; ${ }^{4}$ Faculty of Medicine, School of Health Sciences, Faculty of Medicine, Universidad Pontificia Bolivariana; ${ }^{5}$ Pediatrics Coordination, \\ Clínica Las Américas. Medellin, Colombia
}

\begin{abstract}
Introduction: To determine the clinical and epidemiological profile of the pediatric population diagnosed with central nervous system (CNS) tumors treated in a third-level care institution in Medellin, Colombia, between 2010 and 2015. Methods: Observational, descriptive and retrospective study, which includes the information from clinical records of pediatric patients between 0 and 14 years of age with clinical diagnosis and/or imaging of CNS tumors. The analysis was carried out with the SPSS ${ }^{\circ}$ program. Results: 85 children with CNS tumors were included; the average age of diagnosis was 5.7 years. The main clinical findings were headache $41.2 \%$, and nausea and/or vomiting $29.4 \% .74 .1 \%$ of the tumors were of primary origin and only $8.2 \%$ was secondary to metastasis; the main location was posterior fossa with $22.4 \%$. Conclusion: Despite the fact that the results of this study coincide with what has been described in the literature, it was possible to demonstrate that epidemiological studies with a larger sample are needed, which would make possible to evaluate other variables that allow the characterization of neoplasms of the nervous system in the pediatric population.
\end{abstract}

Key words: Brain neoplasms. Central nervous system. Pediatrics. Neoplasm metastasis. Health profile.

\section{Características clínicas y epidemiológicas de niños con tumores del sistema nervioso central en Medellín, Colombia}

\section{Resumen}

Introducción: Describir las características clínicas y epidemiológicas de los niños con diagnóstico de tumores del sistema nervioso central (SNC) atendidos en una institución de tercer nivel de complejidad de Medellín, Colombia, entre los años 2010 y 2015. Métodos: Estudio descriptivo retrospectivo, en el que se incluyó la información consignada en la historia clínica de los pacientes de 0 a 14 años con diagnóstico clínico y/o imagenológico de tumores del SNC. Resultados: Se incluyeron 85 niños con tumores del SNC, la edad promedio de diagnóstico fue de 5.7 años. Los principales hallazgos clínicos fueron cefalea (41.2\%) y las náuseas y/o vómitos (29.4\%). El $74.1 \%$ de los tumores eran de origen primario y un $8.2 \%$ secundarios a metástasis, la principal localización fue la fosa posterior con un 22.4\%. Conclusión: A pesar de que los resultados de este estudio coinciden con lo descrito en la literatura, se pudo evidenciar que hacen falta estudios epidemiológicos

\section{Correspondence:}

*Lina M. Martínez-Sánchez

E-mail: linam.martinez@upb.edu.co
Date of reception: 19-10-2019

Date of acceptance: 06-02-2020

DOI: 10.24875/j.gamo.M20000199
Available online: 04-08-2020 Gac Mex Oncol. 2020;19(3):1-4 www.gamo-smeo.com 1665-9201/@ 2020 Sociedad Mexicana de Oncología. Published by Permanyer. This is an open access article under the terms of the CC BY-NC-ND license (http://creativecommons.org/licenses/by-nc-nd/4.0/). 
con una muestra mayor, que posibilite evaluar otras variables que permitan caracterizar las neoplasias de sistema nervioso en población pediátrica.

Palabras clave: Neoplasias encefálicas. Sistema nervioso central. Pediatría. Metástasis de la neoplasia. Perfil de salud.

\section{Introduction}

Central nervous system (CNS) tumors include malignant and non-malignant tumors of the brain and spinal cord, with the former group corresponding to the second cause of malignancy in children, after hematologic malignancies, and being the most common cause of solid organ tumors in pediatrics. These neoplasms include brain, meningeal, and spinal cord tumors, with $80 \%$ to $90 \%$ corresponding to brain tumors ${ }^{1-5}$. There are two classification systems to categorize CNS tumors in children: the World Health Organization Classification, according to histology and molecular parameters, and the International Pediatric Cancer Classification according to the site and morphology of the primary tumor ${ }^{6}$.

Unlike adults, primary CNS tumors predominate in children, and approximately one third are located in the posterior fossa. In the USA, between 2008 and 2012, CNS tumors main histological groups in children were gliomas, followed by embryonal tumors?

There are racial and geographic differences in the distribution of CNS malignancies, in addition to different risk factors that can be related to the occurrence of these tumors in childhood ${ }^{8}$. Around $4 \%$ of tumors have been reported to be associated with hereditary syndromes or to be of multifactorial etiology, with the most common being: type I and II neurofibromatosis, tuberous sclerosis, von Hippel-Lindau disease, familial polyposis syndrome and nevoid basal cell carcinoma syndrome ${ }^{9}$. According to the American Cancer Society, "the best known environmental risk factor for brain tumors is radiation exposure, most often from radiation therapy to treat some other condition"2,10.

CNS tumors can cause signs and symptoms depending on the degree of local invasion, compression of adjacent structures, and increased intracranial pressure ${ }^{11-13}$.

There are few data in Antioquia on local epidemiology and clinical characteristics of these tumors. For this reason, the purpose of this study was to determine the clinical and epidemiological profile of children diagnosed with CNS tumors, treated in a tertiary care institution of Medellin, Colombia, between 2010 and 2015.

\section{Material and methods}

A retrospective, descriptive study was carried out, which included all patients aged 0 to 14 years with clinical and/or imaging diagnosis of CNS tumors, who were treated in a tertiary care institution in Medellin (Colombia) between January 2010 and December 2015. The researchers used a form for the registration of information obtained from patient records, which included demographic and clinical data.

The statistical analysis was carried out with the SPSS $^{\circledR}$ V.24 program. Descriptive measures of all the variables were calculated: for age, average, standard deviation, and minimum and maximum values were estimated, and for the rest of the variables, absolute and relative frequencies were calculated (with the latter being the ratio of cases with the characteristic of interest between total number of patients multiplied by 100).

The investigation was approved by the Ethics Committee of the involved institutions and was classified as a risk-free investigation according to Resolution 008430 of 1993 of the Colombian Ministry of Health.

\section{Results}

In total, 85 children with CNS tumors were included, with an average age at diagnosis of $5.7 \pm 3.3$ years and an age at the time of the study of $8.6 \pm 3.7$ (minimum $=1$, maximum $=14$ ). Regarding the main sociodemographic characteristics of the population, the female gender represented $55.3 \%$, urban origin $57.7 \%$ and $74.1 \%$ belonged to the Colombian contributory Regime of Social Security for Health. A personal history associated with CNS tumors was found in $34.1 \%$ of patient records, which corresponded to a convulsive episode, endocrine disorder, and traumatic brain injury in $20 \%, 8.2 \%$, and $3.5 \%$, respectively; only $2.4 \%$ had a history of sarcoma.

Regarding the presence of craniofacial clinical signs, only $16.6 \%$ had this information recorded. The most common signs and symptoms in the study population were headache $(41.2 \%)$, nausea and/or vomiting (29.4\%) and motor symptoms (28.2\%).

The most widely used diagnostic and paraclinical methods were magnetic resonance imaging (MRI) and complete blood count, with $67.1 \%$ and $63.5 \%$ respectively. On paraclinical examination, abnormal results were observed more frequently in complete blood count, electrolyte panel and C-reactive protein (CRP), with $25.9 \%$, $15.3 \%$ and $9.4 \%$ respectively. Regarding tumor characteristics, $74.1 \%$ were observed to be of primary origin, 
and only $8.2 \%$ were secondary to metastasis; it should be noted that the main location was the posterior fossa and the main histological variant was medulloblastoma, both with $22.4 \%$. At least $55.3 \%(14 / 85)$ of the tumors were observed to be malignant, while $16.5 \%$ (47/85) were benign, and for the rest there was no information available. According to the reports on clinical stage, $18.8 \%(16 / 85)$ were at an initial stage, and $14.1 \%(12 / 85)$ were at advanced stage. As for the type of treatment used, surgical resection was the most common with $87.1 \%$, followed by chemotherapy and radiotherapy, with $47.1 \%$ and $21.2 \%$, respectively.

The main complication that was observed as being secondary to the treatment used was infection (non-meningitis), followed by any neurological alteration, with $15.3 \%$ and $14.1 \%$ respectively. Considering the high percentage of patient records without information on patient status, 6-month survival after diagnosis was at least $68.2 \%$ (58/85), dropping to at least $60 \%$ (51/85) at 12 months.

\section{Discussion}

In the study carried out by Azad et al. ${ }^{14}$ in 39 children with CNS tumors, they reported that $61.5 \%$ were males, with an average age of 10 years, which is different from our findings in the above-presented results, where the female gender predominated, with $55.3 \%$, and an average age of 5.7 years was obtained. In the study carried out in Cartagena, Colombia, by Ramos-Clason et al. ${ }^{5}, 53.4 \%$ of males with an average age of 8 years were reported in 58 children with CNS tumors. On the other hand, an Iranian study with 198 children found that $63.1 \%$ (125) corresponded to the male gender, a result that is consistent with that reported by Azad et al. ${ }^{15}$. As for clinical manifestations, headache and hemiparesis were the most frequently reported symptoms by Azad et al. ${ }^{14}$, with $27 \%$ and $24.3 \%$ respectively, which are figures comparable with the data observed by our team, where the main symptoms were headache and nausea and/or vomiting with $41.2 \%$ and $29.4 \%$, respectively, in contrast with the study conducted by Suresh et al. $^{16}$ in southern India, where the main symptom was vomiting, with $62.5 \%$, followed by headache in $37.5 \%$. In concordance with Suresh et al. ${ }^{16}$ findings, in the study by Faranoush et al. ${ }^{15}$, vomiting ( $\mathrm{n}$ $=106,53.5 \%)$ and headache $(n=102,51.5 \%)$ were the main clinical findings. The indications for performing a neuroimaging examination are based on the index of suspicion with regard to the signs and symptoms observed in a patient; therefore, in every child with persistent headache (continuous or recurrent, for more than 4 weeks), a CNS tumor should be suspected, and neuroimaging examination is required to rule it out ${ }^{17,18}$. The results presented in this manuscript show that MRI was performed in $67 \%$ of children and computed tomography in $57 \%$. Biopsy was obtained only in $37 \%$ of cases. Regarding the location of brain tumors, a frequency of posterior fossa tumors was found in $22.4 \%$, which is similar to that reported by Ostrom et al. ${ }^{7}$, whose five most frequent locations were: cerebellum, with $18.5 \%$; other brain regions, with $15.2 \%$; brainstem, with $12.4 \%$, followed by pituitary and craniopharyngeal duct $(8.1 \%)$ and cranial nerve tumors (7.5\%). As regards histological variants, Azad et al..$^{14}$ reported that the most common was ependymoma, with $19.4 \%$, followed by pilocytic astrocytoma and medulloblastoma with $16.7 \%$ each, while, in our findings, the most common was medulloblastoma with $22.4 \%$, followed by pilocytic astrocytoma and neuroectodermal tumor with $16.5 \%$ and $8.2 \%$, respectively; similarly, Shirazi et al. ${ }^{19}$ found medulloblastoma $(n=11,20.37 \%)$ to be the most common neoplasm. In turn, Zhou et al. ${ }^{20}$, in their study carried out in China with 1,485 cases, found astrocytoma $(31 \%)$, craniopharyngioma (18\%), medulloblastoma $(15 \%)$, germ cell tumors $(8 \%)$ and ependymal tumors $(6 \%)$ to be the most common CNS tumors. The results obtained in the study by Faranoush et al. ${ }^{15}$, show high-grade glioma and medulloblastoma as the main neoplasms that were found, with $59.99 \%$ and $48.51 \%$ of supratentorial and infratentorial tumors, respectively. The research team found that the most widely used treatment was surgery, performed in $87.1 \%$, which is a similar figure to that reported by Azad et al. ${ }^{14}, 80 \%$, out of which $52.5 \%$ required additional surgeries, while in our population only $14.1 \%$ were re-operated. Similarly, in the study carried out by Suresh et al. ${ }^{16}$, surgery was described in $69 \%$ of cases. Regarding other types of treatment, Suresh et al. ${ }^{16}$ reported radiotherapy and chemotherapy in $53.8 \%$ and $50 \%$ respectively, which are dissimilar data to those herein reported, where chemotherapy and radiotherapy were reported in $47.1 \%$ and $21.2 \%$, respectively. Radiotherapy and chemotherapy are adjuvant treatments and are based on tumor histology ${ }^{21}$. The survival rate depends on each tumor: in the USA, 5- and 10 -year survival for children with CNS tumors was $73 \%$ and $70 \% \%^{7}$. Children who survive CNS tumors generally have neurological, cognitive, psychological and endocrine sequelae secondary to the tumor itself and to the treatment that is used. The risk for these sequelae increases in younger patients (younger than 3 years) 
at the time of diagnosis and treatment, and in children with hydrocephalus and/or previous treatment with radiation therapy to the skull22.

\section{Conclusion}

With this study, the clinical and epidemiological profile of 85 children with CNS tumors treated at an institution in Medellin can be characterized, with the main symptoms being headache and nausea and/or vomiting. The main histological variant for this population was medulloblastoma, unlike other studies carried out in other developed and developing countries. The one-year survival rate of these patients was $60 \%$, which is lower than that previously reported. However, more local epidemiological studies are needed where a larger number of patients are included, where a long-term follow-up is allowed in order to assess the presence of transient and permanent sequelae and survival after more years of diagnosis and treatment.

\section{Funding}

Funding of the project was in charge of Universidad Pontificia Bolivariana.

\section{Conflict of interests}

The authors declare that they have no conflicts of interest.

\section{Ethical disclosure}

Protection of people and animals The authors declare that no experiments were performed on humans or animals for this research.

Confidentiality of data The authors declare that they have followed the protocols of their work center on the publication of patient data.

Right to privacy and informed consent The authors declare that no patient data appear in this article.

\section{References}

1. Linabery AM, Ross JA. Trends in childhood cancer incidence in the U.S. (1992-2004). Cancer. 2008;112(2):416-32.
2. Morales M, Sánchez-Vergara AL, Rubio-López N, Llopis-González A. Exposición a factores ambientales y riesgo de tumores en el sistema nervioso central en niños: revisión sistemática y meta-análisis. Rev Salud Ambient. 2014;14(2):74-86.

3. Arias Andrade MV, Maya Hijuelos LC (dir), Godoy Cordobés JA (dir), Vásquez Hoyos P (dir). Caracterización de los pacientes atendidos en la Unidad de Cuidado Intensivo pediátrica del Instituto Nacional de Cancerología, Bogotá, Colombia [Tesis para título de especialista en Internet]. [Bogotá, Colombia]: Universidad Nacional de Colombia, Facultad de Medicina, Departamento de Pediatría; 2014. Disponible en: http://bdigital. unal.edu.co/12443/1/5599667.2014.pdf

4. Pardo C, Cendales R. Incidencia, mortalidad y prevalencia de cáncer en Colombia, 2007-2011. Primera edición. Bogotá D.C.: Instituto Nacional de Cancerología; 2015.

5. Ramos-Clason E, Tuñón-Pitalua M, Rivas-Muñoz F, Veloza-Cabrera L. Tumores primarios del sistema nervioso central en Cartagena, 20012006. Rev Salud Pública. 2010;12(2):257-67.

6. Louis DN, Perry A, Reifenberger G, von Deimling A, Figarella-Branger D, Cavenee WK, et al. The 2016 World Health Organization Classification of Tumors of the Central Nervous System: a summary. Acta Neuropathol. 2016;131(6):803-20.

7. Ostrom QT, Gittleman H, Fulop J, Liu M, Blanda R, Kromer C, et al. CBTRUS Statistical Report: Primary brain and central nervous system tumors diagnosed in the United States in 2008-2012. Neuro Oncol. 2015;17(Suppl 4):iv1-iv62.

8. Villarejo F, Martínez J. Tumores cerebrales en niños. Pediatr Integral. 2012;XVI(6):475-86.

9. Martínez González MJ, García Ribes A, Garaizar Axpe C. Tumores cerebrales infantiles: diagnóstico y semiología neurológica [Internet]. Madrid: Asociación Española de Pediatría; 2008 [consultado: 16 de enero de 2018]. Disponible en: https://www.aeped.es/sites/default/files/documentos/27-tumores.pdf

10. Taylor AJ, Little MP, Winter DL, Sugden E, Ellison DW, Stiller CA, et al. Population-based risks of CNS tumors in survivors of childhood cancer: the British Childhood Cancer Survivor Study. J Clin Oncol. 2010;28(36):5287-93.

11. Wilne SH, Dineen RA, Dommett RM, Chu TP, Walker DA. Identifying brain tumours in children and young adults. BMJ. 2013;347:f5844.

12. Fischman M, Ismael J, Pesce P, Rufach D. Tumores pediátricos del sistema nervioso central [Internet]. Argentina: Instituto nacional de Cáncer; 2015 [consultado: 16 de enero de 2018]. Disponible en: http://www.msal.gob.ar/ images/stories/ bes/graficos/ 0000000811cnt-67-tumores-del-SNC.pdf

13. Wilne S, Collier J, Kennedy C, Koller K, Grundy R, Walker D. Presentation of childhood CNS tumours: a systematic review and meta-analysis. Lancet Oncol. 2007;8(8):685-95.

14. Azad TD, Shrestha RK, Vaca S, Niyaf A, Pradhananga A, Sedain G, et al. Pediatric central nervous system tumors in Nepal: Retrospective analysis and literature review of low- and middle-income countries. World Neurosurg. 2015;84(6):1832-7.

15. Faranoush M, Torabi-Nami M, Mehrvar A, HedayatiAsl AA, Tashvighi M, Parsa RR, et al. Classifying pediatric central nervous system tumors through near optimal feature selection and mutual information: A single center cohort. Middle East J Cancer. 2013;4(4):153-62.

16. Suresh SG, Srinivasan A, Scott JX, Rao SM, Chidambaram B, Chandrasekar S. Profile and outcome of pediatric brain tumors - Experience from a tertiary care pediatric oncology unit in South India. J Pediatr Neurosci. 2017;12(3):237-44.

17. Matthews PM, Wylezinska M, Cadoux-Hudson T. Novel approaches to imaging brain tumors. Hematol Oncol Clin North Am. 2001;15(4):609-30.

18. Wilne S, Koller K, Collier J, Kennedy C, Grundy R, Walker D. The diagnosis of brain tumours in children: a guideline to assist healthcare professionals in the assessment of children who may have a brain tumour. Arch Dis Child. 2010;95(7):534-9.

19. Shirazi N, Gupta M, Bhat NK, Kalra BP, Kumar R, Saini M. Profile of primary pediatric brain and spinal cord tumors from North India. Indian J Med Paediatr Oncol. 2017;38:10-4.

20. Zhou D, Zhang Y, Liu H, Luo S, Luo L, Dai K. Epidemiology of nervous system tumors in children: a survey of 1,485 cases in Beijing Tiantan Hospital from 2001 to 2005. Pediatr Neurosurg. 2008;44(2):97-103.

21. Blaney SM, Hass-Kogan D, Poussaint TY, et al. Gliomas, ependymomas, and other nonembryonal tumors of the central nervous system. En: Pizzo P, Poplack D (editores). Principles and practice of pediatric oncology, 6th ed. Philadelphia: Wolters Kluwer Health/Lippincott Williams \& Wilkins; 2011. p. 717.

22. Fouladi M, Gilger E, Kocak M, Wallace D, Buchanan G, Reeves C, et al. Intellectual and functional outcome of children 3 years old or younger who have CNS malignancies. J Clin Oncol. 2005;23(28):7152-60. 